\title{
Effect of Concurrent Training and Supplementation with $\beta$-Hydroxy- $\beta$-Methylbutyirate (HMB) on the Prostate: Alterations in the Androgen Receptor and Inflammation
}

\author{
Efecto del Entrenamiento Concomitante y Suplementación con $\beta$-Hidroxi- $\beta$-Metilbutirato \\ (HMB) en la Próstata: Alteraciones en el Receptor de Andrógenos y la Inflamación
}

\begin{abstract}
Danilo Bianchini Baptista ${ }^{1}$; Luis Felipe Dutra de Santana ${ }^{1}$; Allice Santos Cruz Veras ${ }^{1}$; Verônica Alves de Menezes ${ }^{1}$; Nilton José dos Santos²; Marcelo Papoti³; José Carlos Silva Camargo Filho ${ }^{4}$ \& Giovana Rampazzo Teixeira ${ }^{1}$
\end{abstract}

BAPTISTA, D. B.; DUTRA DE SANTANA, L. F.; VERAS, C. A. S. ; ALVES DE MENEZES, V.; DOS SANTOS, N. J.; PAPOTI, M.; CAMARgO FILHO, J. C. S. \& TEIXEIRA, G. R. Effect of concurrent training and supplementation with $\beta$-hydroxy- $\beta$ methylbutyirate (HMB) on the prostate: alterations in the androgen receptor and inflammation. Int. J. Morphol., 36(1):74-79, 2018.

SUMMARY: Supplementation is a strategy to potentiate physical training through hypertrophy of skeletal muscles, but other tissues such as the prostate may also be affected. Changes in prostate size and function are associated with the behavior of individuals, but evidence for an association with supplementation is scarce. Therefore, the aim of our study was to evaluate the effect of b-hydroxy bmethylbutyrate (HMB) supplementation and concurrent training on the prostate. Wistar rats were divided randomly into four groups with 10 animals each: control group (C), supplemented group (S), training group (T), and supplemented plus training group (TS). The supplemented groups (S and TS) received $76 \mathrm{mg} \cdot \mathrm{kg} /$ day of HMB and the concurrent training groups (T and TS) performed exercise three times per week for eight weeks. HMB increased body composition, total weight of the prostate, and altered the histology of prostatic compartments. The lateral prostate of animals in the supplemented group had an increase in mast cells per $\mathrm{mm}^{2}(28.0 \pm 3.9)$ compared to the control and exercise group $(6.1 \pm 3.0 ; 2.3 \pm 0.9)$ There was also an increase in inflammation in the stroma and lumen of the prostate, and increased expression of androgen receptor (AR) in the supplemented and trained supplemented group $(79.8 \pm 2.1 ; 76.8 \pm 11.4)$ in relation to the trained group $(61.5 \pm 7.0)$. We concluded that HMB alters hormone receptors that induce morphological changes and inflammation, and animals in the concurrent training group had normal inflammatory and hormonal profiles, and favorable prostatic histology.

KEYS WORDS: Supplementation; Concurrent training; HMB; Prostate; Androgen receptor.

\section{INTRODUCCIÓN}

Currently, supplementation strategies and resistance training have been widely used to increase strength and muscle hypertrophy. $\beta$-hydroxy $\beta$-methylbutyrate (HMB) is a leucine metabolite synthesized in the liver and muscle cells from a-ketoisocaproate (KIC), and HMB can be processed in two ways: into cholesterol through HMG-CoA reductase, or into acetyl-CoA through HMG-CoA synthase for power supply (Pimentel et al., 2011). Studies from our laboratory demonstrated that eight-week HMB supplementation associated with concurrent training was effective in promoting skeletal muscle adaptations, such as increased strength and cross-sectional size of muscle fibers (Teixeira et al., 2016).
Concurrent training is characterized by strength and endurance training in the same training session. Additionally, concurrent training is necessary for sports whereby improved strength, power, and/or hypertrophy are desired with enhanced aerobic capacity (Helgerud et al., 2011).

HMB supplementation and concurrent training has been widely investigated as a therapeutic approach to reduce muscle mass loss related to age and to improve cancerinduced cachexia through the reduction of proteolysis (Düvel et al., 2010). The molecular mechanisms are associated with stimulation of the mTOR/p70S6K pathway, promoting protein synthesis and decreasing catabolic hormones, such

\footnotetext{
${ }^{1}$ Department of Physical Education, São Paulo State University (UNESP), School of Technology and Sciences, Presidente Prudente, SP, Brazil.

${ }^{2}$ Department of Structural and Functional Biology, Institute of Biology, University of Campinas (UNICAMP), Campinas, SP, Brazil.

${ }^{3}$ Department of Physical Education and Sports, University of São Paulo (USP), Ribeirão Preto, SP, Brazil.

${ }^{4}$ Department of Physiotherapy, São Paulo State University (Unesp), School of Technology and Sciences, Presidente Prudente, SP, Brazil.
} 
BAPTISTA, D. B.; DUTRA DE SANTANA, L. F.; VERAS, C. A. S. ; ALVES DE MENEZES, V.; DOS SANTOS, N. J.; PAPOTI, M.; CAMARGO FILHO, J. C. S. \& TEIXEIRA, G. R. Effect of concurrent training and supplementation with $\beta$-hydroxy- $\beta$-methylbutyirate (HMB) on the prostate: alterations in the androgen receptor and inflammation. Int. J. Morphol., 36(1):74-79, 2018.

as cortisol (Pimentel et al.). Studies have observed an increase in pituitary Growth Hormone $(\mathrm{GH})$ mRNA and protein expression after one month of HMB supplementation (Gerlinger Romero et al., 2011). A major concern of nutritional supplementation in patients with cancer is the theoretical risk of feeding the tumor, particularly when molecules that might have anabolic activity are used.

Prostate cell growth and differentiation occur by induction of androgens and their binding at the androgen receptor (AR). However, other pathways may contribute through insulin-like growth factor-1 (IGF-1), fibroblast growth factor (FGF), transforming growth factor beta (TGFb), and others (Powers \& Marker, 2013). In the prostate, mTOR (activated by HMB) regulates cellular metabolism by controlling glucose uptake, glycolysis, fatty acid metabolism, and the pentose phosphate pathway (Manning \& Cantley, 2007). In particular, mTORC1 promotes cell proliferation and anabolic reactions. AR positively regulates mTOR signaling. Given the critical role of the PI3K-AKTmTOR pathway in normal cell physiology, it is not surprising that the pathway is deregulated in a vast array of cancers. Thus, hormonal changes and anaerobic protein increase may stimulate prostatic diseases associated with cell proliferation. However, clarifications are required about the stimulated molecular pathways.

Therefore, the objective of our study was to evaluate the effect of 8 weeks of HMB supplementation, concurrent physical training and the association of the two interventions on androgen receptor expression and the morphological and inflammatory changes of the lateral prostate of Wistar rats.

\section{MATERIAL AND METHOD}

Accommodation of animals. The present experimental protocol was approved by the ethical committee of the FCT/ UNESP, campus Presidente Prudente, SP, Brazil (Protocol number 03/2011, Chairperson: Raul Antonio Fragoso Neto). After a period of environmental adaptation, 40 Wistar rats used in the experiments were randomly divided into 4 groups: Control (C); Supplementation with HMB (S); Training group (T); Training + HMB supplementation (TS). At 140 days old, the animals were euthanized according to the Canadian Council on Animal Experimentation.

HMB Supplementation. Supplementation with HMB (Trade Mark Arnold Nutrition Inc., Hollywood, FL) began at the same time as concurrent training (at 81 days old). The animals in the HMB supplementation groups received doses by gavage (30 min before the concurrent training protocol) in a single dose of $76 \mathrm{mg} / \mathrm{kg} /$ day. This dosage is equivalent to what is used in studies involving HMB supplementation in humans (Gallagher et al., 2000), which corresponds to about 3-6 g/day of HMB for a subject weighing $80 \mathrm{~kg}$.

Concurrent Training Program. At 81 days old, the animals began adaptation to a water environment to reduce stress from exercise. For groups assigned to concurrent training ( $\mathrm{T}$ and TS), the adaptation period lasted three weeks and included increasing swimming sessions

The protocol started with aerobic training followed by anaerobic training with no breaks between the different training elements. The aerobic endurance training was composed of a swimming session lasting 38 min conducted in PVC cylindrical tanks. A vest was placed on the anterior chest region of the animal with a constant overload, according to the percentage of body weight of each animal, as previously established by a lactate minimum test corresponding to $70 \%$ of the anaerobic threshold. For Strength Training, the animals performed a series of jumps in a cylindrical PVC container $(90 \times 60 \mathrm{~cm})$ with water at $30 \pm 1{ }^{\circ} \mathrm{C}$ and a depth of $40 \mathrm{~cm}$. The training program lasted eight consecutive weeks. The jumping sessions were composed of 4 sets of 10 jumps with 1-minute rest between sets. The overload used was constant, equivalent to $50 \%$ of the body weight of each animal fixed to the anterior chest with a vest shaped specifically for this type of jump (De Mello Malheiro et al., 2009, Teixeira et al., 2016).

Aerobic and anaerobic performances. Aerobic and anaerobic performances were measured by intensity timeout (Tlim). To define these variables, we used a protocol validated previously for humans, applied to rats (Voltarelli et al., 2002), and refined (de Araujo et al., 2007).

Anthropometric, histological, and histochemical analysis. During the experiment, measurements of body weight were taken from the animals. Body weight was measured using an electronic scale (Shimadzu BL3200H, with a precision of $0.01 \mathrm{~g}$ ).

At 140 days old, the animals were sedated with ketamine $(50 \mathrm{mg} / \mathrm{kg})$ and xilasin $(10 \mathrm{mg} / \mathrm{kg})$ to minimize pain $48 \mathrm{~h}$ after the last training session and the lateral prostate was collected. Stereology tissue volume was measured by reticle 160 points of Weibel (Weibel et al., 1966) on animals stained with $\mathrm{H} / \mathrm{E}$.

For mast cell count per $\mathrm{mm}^{3}$, the slides were stained with toluidine blue. The counting was performed in the lateral prostate on four areas per cut with a magnification of 400x. 
BAPTISTA, D. B.; DUTRA DE SANTANA, L. F.; VERAS, C. A. S. ; ALVES DE MENEZES, V.; DOS SANTOS, N. J.; PAPOTI, M.; CAMARGO FILHO, J. C. S. \& TEIXEIRA, G. R. Effect of concurrent training and supplementation with $\beta$-hydroxy- $\beta$-methylbutyirate (HMB) on the prostate: alterations in the androgen receptor and inflammation. Int. J. Morphol., 36(1):74-79, 2018.

Immunohistochemistry Samples of the lateral prostate obtained from the animals in each group were fixed in $10 \%$ formalin solution, embedded in paraffin and cut into 4-mm thick sections. The technique used is described briefly by Fávaro \& Cagnon (2006). The prostate marker studied is the androgen receptor (AR) - N20 Santa Cruz antibody.

Statistical analysis. Statistical analysis was performed using a two-way ANOVA and complemented with the Tukey test. Variables with non-normal distribution were treated with non-parametric statistics using Kruskal-Wallis analysis. Statistical significance was set at $5 \%$. The statistical software used was IBM SPSS Statistics version 22. GraphPad Instat version 4 and Sigma Plot version 11.0 were used for the graphics.

\section{RESULTS}

The supplementation group had significantly higher values of body weight gain, body mass index (BMI), total weight of the prostate, and relative weight of the prostate compared with the control and trained groups (Fig. 1A-C, respectively).

The values of prostate stereology expressed in percentage showed that the TS group had a significant increase in epithelium size and reduced lumen compared with the $\mathrm{C}$ and $\mathrm{T}$ groups (Fig. 1F). The volume of epithelium and stromal tissue was significantly lower in the $\mathrm{T}$ group compared with the $\mathrm{S}$ and TS groups. There was a significant increase of lumen in the $\mathrm{T}$ and $\mathrm{C}$ groups when compared to $\mathrm{S}$ and TS groups (Fig.
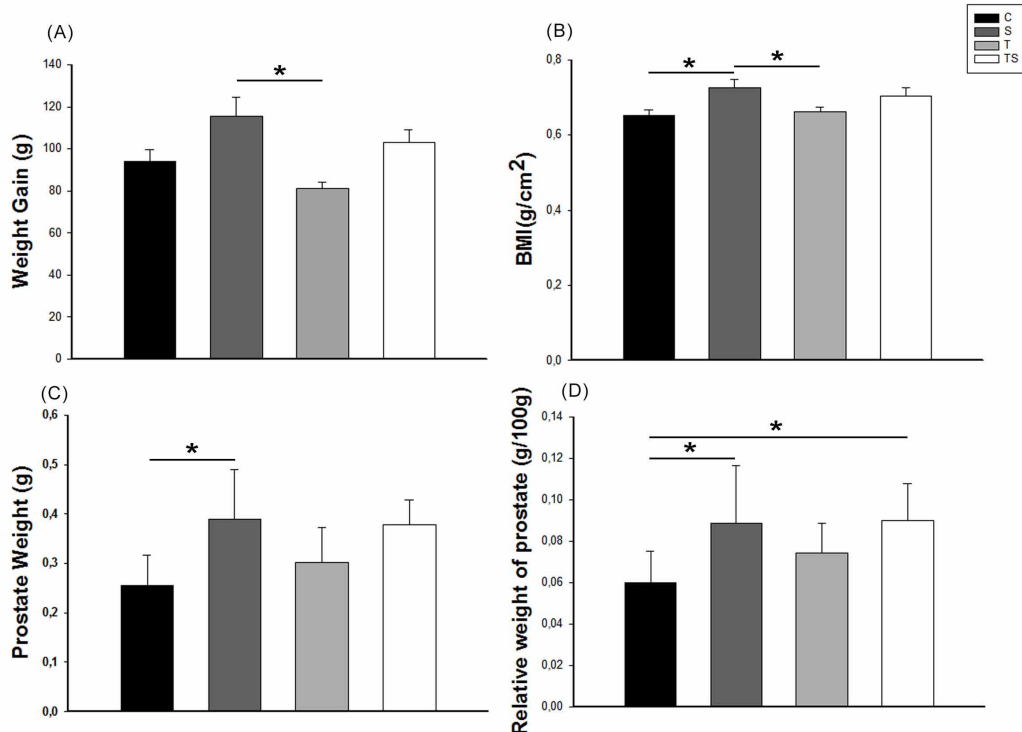

(E)
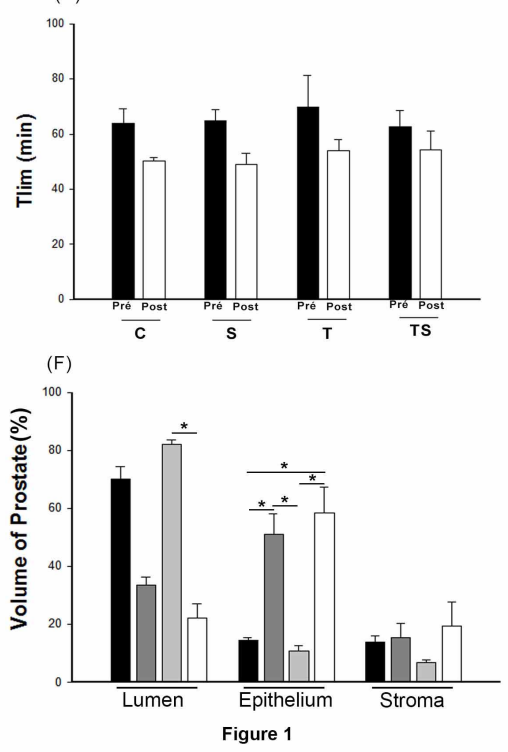

1F). Fig. 2A-D shows that the microscopic morphology of the lateral prostate had a variety of small and medium acini, covered with a thick layer of connective tissue (stroma), plus interstitial space. Morphological analysis of tissues from HMB supplementation showed increased inflammation in the stroma and the acinus, characterizing prostatitis (Figs. 2B and B1; $\mathrm{D}$ and D1). The TS group had softened morphological changes of the lateral prostate reducing the amount of prostatitis and had reduced epithelium. The location of the mast cells was maintained in the fibromuscular stroma, near the epithelium. HMB supplementation promoted an increase in the number of mast cells per $\mathrm{mm}^{2}$ in group $\mathrm{S}(28.0 \pm 3.9, \mathrm{p}=0.001)$ and TS $(21.7 \pm 3.6, p=0.001)$ compared to groups $\mathrm{C}(6.1 \pm 3.0, \mathrm{p}=0.001)$ and $\mathrm{T}(2.3$ $\pm 0.9, \mathrm{p}=0.001)$. AR expression increased in the $\mathrm{S}$ group $(79.8 \pm 2.1)$ and and TS groups $(76.8 \pm 11.4, \mathrm{p}=0.036)$ compared to $\mathrm{T}(61.5 \pm 7.0, \mathrm{p}=0.012)$. AR expression was lower in the T group.

Fig. 1. (A) weight gain (g) after eight weeks of treatment. (B) body mass index $\left(\mathrm{cm}^{2}\right)$ of animals. (C) prostate weight $(\mathrm{g})$ of animals. (D) Relative weight of the prostate of the animals (in $\mathrm{g} / 100 \mathrm{~g}$ of body weight). (E) Tlim values after application of protocols. (F) Graphic representation of changes in prostatic compartments (lumen, epithelium and stroma) of animals under supplementation and concurrent training (Statistical difference between the compartments). $*=p<0.05$. 

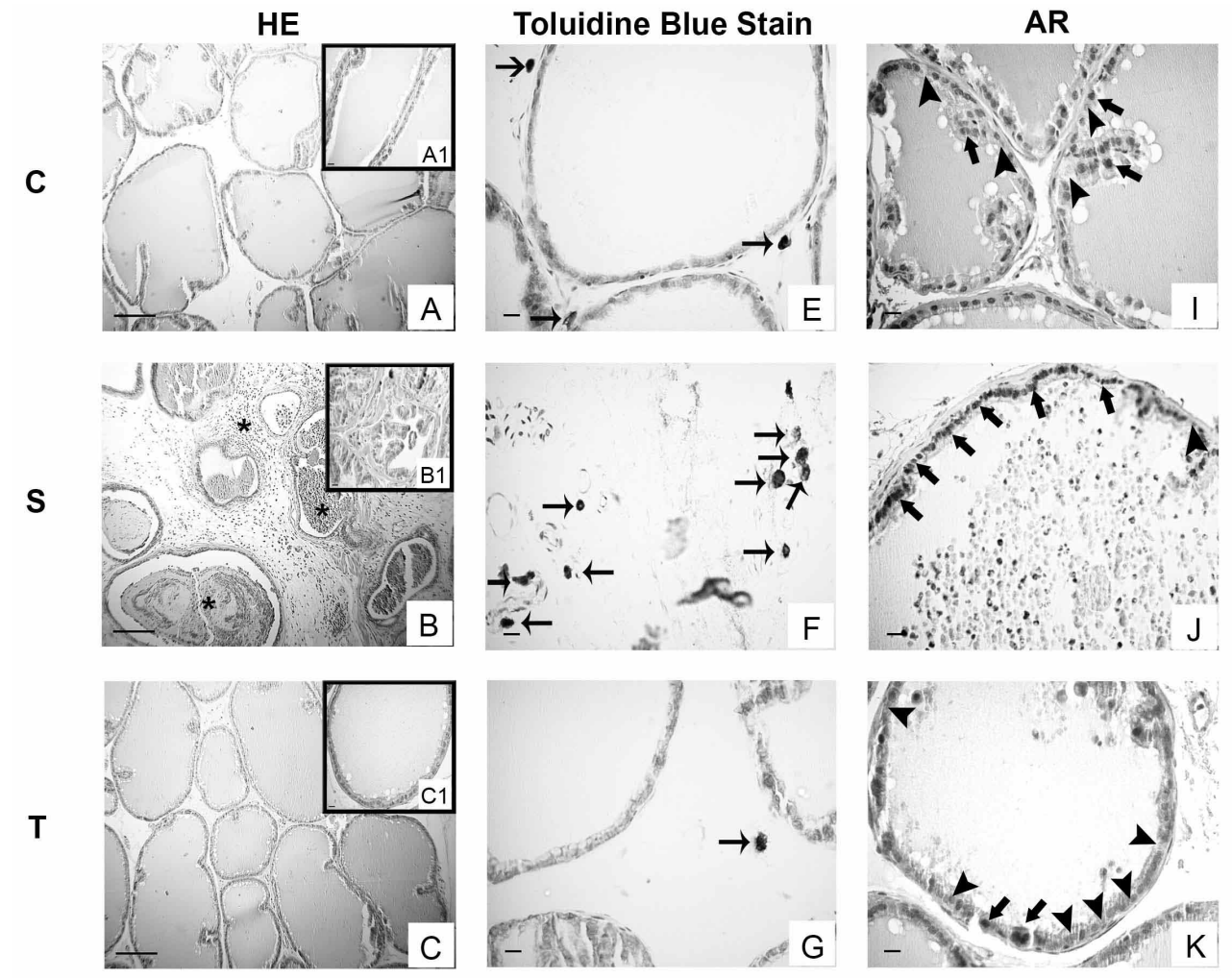

TS
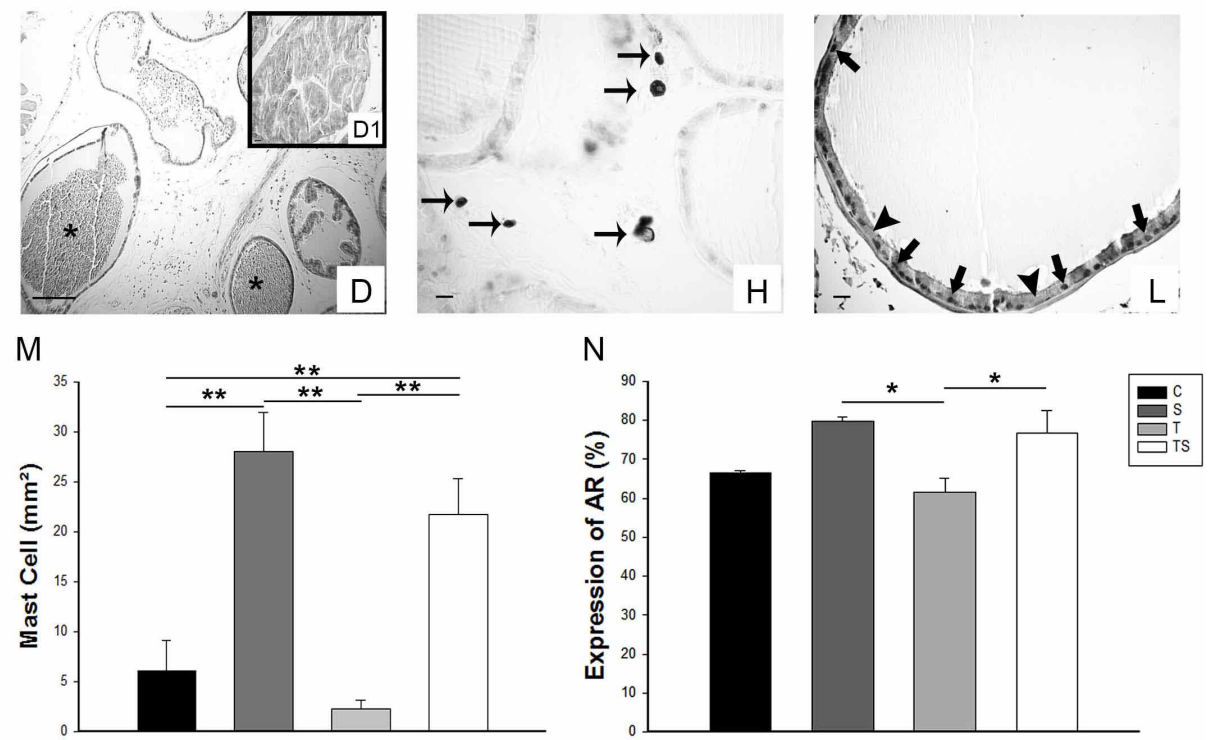

Fig. 2. Morphological distribution of the prostate undergoing staining in HE, Toluidine Blue Stain, and Immunomarcation for AR. The images A, A1, E and I represent the group Co. The images B, B1, F and $\mathrm{J}$ refer to the $\mathrm{S}$ group. The images $\mathrm{C}, \mathrm{C} 1$, g and $\mathrm{K}$ represent the T group and the images D, D1, $\mathrm{H}$ and $\mathrm{L}$ are related to the $\mathrm{T}$. The figure $\mathrm{M}$ represent the number of mast cells per $\mathrm{mm}^{3}$ and Figure $\mathrm{N}$ represents the marked cells of AR through immunohistochemistry. $*=p<0.05$ and $* *=p<0,01$. The first column represents the general prostatic morphology through $\mathrm{HE}$, images with an increase of $10 \mathrm{x}(\mathrm{Bar}=50 \mathrm{~mm})$ under the microscope and with a detail increased 40x (Bar = $20 \mathrm{~mm}$ ). The second column (Mastocyte) illustrates the number of mast cells per $\mathrm{mm}^{3}$, and the arrows indicate the location of the mast cells in the stroma $($ Bar $=20 \mathrm{~mm})$. The third column represents the immunomarcation for AR in the epithelial cell nucleus, arrow head indicating unmarked nuclei for AR, and arrows indicating nuclei that are marked for $\mathrm{AR}(\mathrm{Bar}=20 \mathrm{~mm})$ 
BAPTISTA, D. B.; DUTRA DE SANTANA, L. F.; VERAS, C. A. S. ; ALVES DE MENEZES, V.; DOS SANTOS, N. J.; PAPOTI, M.; CAMARGO FILHO, J. C. S. \& TEIXEIRA, G. R. Effect of concurrent training and supplementation with $\beta$-hydroxy- $\beta$-methylbutyirate (HMB) on the prostate: alterations in the androgen receptor and inflammation. Int. J. Morphol., 36(1):74-79, 2018.

\section{DISCUSSION}

The aim of this study was to investigate the effects of HMB and to understand the possible changes in the lateral prostate of normal rats performing concurrent training. The main findings of this study were: A) supplementation of HMB for eight weeks modified weight gain, BMI, and absolute and relative prostate weight; B) the lateral prostate of rats supplemented with HMB had increased epithelium, acinus with chronic inflammation (prostatitis), and high numbers of mast cells in the stroma; C) HMB increased immunolabeling of the AR; D) Concurrent training had a favorable effect without supplementation in the prostate.

Our data demonstrated that HMB supplementation increased the expression of androgen receptors in the prostate. The metabolic pathways in question may be associated with endocrine changes in growth factors and androgenic hormones. Studies have shown that supplementation of HMB for 12 weeks increased body weight and serum concentrations of testosterone and IGF-1 (Kraemer et al., 2009) and may be associated with proliferative stimulation of prostate cells.

The PI3K / Akt / mTOR pathway is a potent stimulator of cell proliferation, and is linked with activation of RA, suggesting that changes in this receptor stimulate uncontrolled cell replication. (Wu et al., 2010). The PI3K / AKT signaling proteins phosphorylate apoptotic regulators such as Forkhead box o (Foxo) and glycogen synthase kinase 3 (GSK3b), to inhibit apoptosis and autophagy in cancer cells (Karrasch et al., 2011) together with AR also stimulates GSKa / $\mathrm{b}$ by potentiating the molecular pathways involved in cell survival. In our findings, the endocrine and metabolic interactions also modulated the compartments of the prostate, especially by the expressive increase of the epithelium. These hypotheses confirm the idea that androgenic stimulation increases cell proliferation, and consequently increases the size of the prostatic epithelium

It has been proposed that physical exercise is an important tool in reducing the development of several cancers, mainly due to its pro-apoptotic role (Friedenreich \& Orenstein, 2002). Data from our group previously revealed a relationship between increased apoptosis and the practice of resistive physical exercise through hormonal control and decreased AR in the prostate. In these results we also demonstrated that concurrent training decreased AR expressions, and therefore both modalities help promote health and favorable prostatic environment. (Teixeira et al., 2012).
The mTORC induced by HMB links amino acids, growth factors, and energy availability to prostate epithelial cell growth, proliferation, motility, autophagy, morphogenesis, and tumorigenesis (Melnik et al., 2012). HMB supplementation increased the number of mast cells in the prostate, and increased stromal and acinar inflammation. PGE2-mediated chemotaxis and chemokine release from mast cells is regulated by mTORC activation, and this is reduced by pretreatment of cells with the active site mTOR inhibitor Torin1 (Misra \& Pizzo, 2013). Our results showed changes in the prostatic epithelium and increased acinar inflammation possibly activated by Akt/ mTOR signaling stimulated by AR.

In other studies, from our group, concurrent training associated with HMB supplementation had positive effects on body composition as well as on skeletal muscle fibers in rats. HMB prevented the loss of fat mass and increased the diameter of the cross-sectional area of muscle fibers, contributing to a change in oxidative metabolism and glycolytic fibers (Teixeira et al., 2016). This mechanism specifically increased the phosphorylation of the anabolic $\mathrm{Akt} / \mathrm{mTOR}$ signaling pathway, and translation activation of the initiation regulators p70S6k, 4E-BP1, and eIF2B. However, a small effect was also observed on the AMPK/ PGC-1 pathway (Aydin et al., 2015). Although the results of HMB supplementation decrease proteolysis, and increase the cross-sectional diameter of the muscle by systemic anabolic pathways, the prostate is also susceptible to these changes by the same stimulations, resulting in increased prostate and morphofunctional changes.

Therefore, we conclude that HMB supplementation increases AR expression in the prostate, resulting in morphofunctional changes in the epithelium characterized by cell accumulation. In addition, we observed an inflammatory increase in the stroma and lumen of the prostatic acini, confirmed after enlargement of mast cells in the supplemented group. In contrast, physical exercise proved to be efficient for the normalization of the histology of the prostate, through the reduction of inflammatory foci and RA. Although HMB is a strategy to prevent muscle mass loss, more attention is needed on the amount and time of supplementation to avoid unwanted interactions with other tissues.

\section{ACKNOWLEDGMENTS}

The authors thank the National Research Council (CNPq) for financial support. (Process number 30700) and the Experimental Laboratory of Exercise Biology (LEBioEx) for the resources to prepare this paper. 
BAPTISTA, D. B.; DUTRA DE SANTANA, L. F.; VERAS, C. A. S. ; ALVES DE MENEZES, V.; DOS SANTOS, N. J.; PAPOTI, M.; CAMARGO FILHO, J. C. S. \& TEIXEIRA, G. R. Efecto del entrenamiento concomitante y suplementación con $\beta$-hidroxi- $\beta$ metilbutirato $(\mathrm{hmb})$ en la próstata: Alteraciones en el receptor de andrógenos y la inflamación. Int. J. Morphol., 36(1):74-79, 2018.

RESUMEN: La suplementación con $\beta$-hidroxi $\beta$-metilbutirato (HMB) es una estrategia para potenciar el entrenamiento físico a través de la hipertrofia de los músculos esqueléticos, pero otros tejidos como la próstata también pueden verse afectados. Los cambios en el tamaño y la función de la próstata están asociados con el comportamiento de las personas, pero la evidencia de una asociación con la suplementación es escasa. Por lo tanto, el objetivo de nuestro estudio fue evaluar el efecto de la suplementación con $\beta$-hidroxi $\beta$ metilbutirato (HMB) y el entrenamiento concurrente en la próstata. Las ratas Wistar se dividieron aleatoriamente en cuatro grupos con 10 animales cada uno: grupo de control (C), grupo suplementado (S), grupo de entrenamiento (T) y grupo de entrenamiento suplementado (TS). Los grupos suplementados (S y TS) recibieron $76 \mathrm{mg} \bullet \mathrm{kg} /$ día de HMB y los grupos de entrenamiento concurrentes (T y TS) realizaron ejercicio tres veces por semana durante ocho semanas. HMB aumentó la composición corporal, el peso total de la próstata y alteró la histología de los compartimentos prostáticos. La próstata lateral de los animales en el grupo suplementado tuvo un aumento en los mastocitos por $\mathrm{mm}^{2}$ $(28,0 \pm 3,9)$ en comparación con el grupo de control y ejercicio $(6,1 \pm$ $3,0 ; 2,3 \pm 0,9)$ También hubo un aumento de la inflamación en el estroma y la luz de la próstata, y aumento de la expresión del receptor de andrógenos (AR) en el grupo suplementado y entrenado $(79,8 \pm 2,1$; $76,8 \pm 11,4)$ en relación con el grupo entrenado $(61,5 \pm 7,0)$. Concluimos que el HMB altera los receptores de hormonas que inducen cambios morfológicos e inflamación, y los animales en el grupo de entrenamiento concurrente tenían perfiles inflamatorios y hormonales normales y una histología prostática favorable.

PALABRAS CLAVE: Suplementación; Entrenamiento concurrente; HMB; Próstata; Receptor de andrógenos.

\section{REFERENCES}

Aydin, M.; Cayonu, N.; Kadihasanoglu, M.; Irkilata, L.; Atilla, M. K. \& Kendirci, M. Comparison of sexual functions in pregnant and non-pregnant women. Urol. J., 12(5):2339-44, 2015.

de Araujo, G. G.; Papoti, M.; Manchado, F. de B.; de Mello, M. A. \& Gobatto, C. A. Protocols for hyperlactatemia induction in the lactate minimum test adapted to swimming rats. Comp. Biochem. Physiol. A Mol. Integr. Physiol., 148(4):888-92, 2007.

De Mello Malheiro, O. C.; Giacomini, C. T.; Justulin, L. A. Jr.; Delella, F. K. Dal-Pai-Silva, M. \& Felisbino, S. L. Calcaneal tendon regions exhibit different MMP-2 activation after vertical jumping and treadmill running. Anat. Rec. (Hoboken), 292(10):1656-62, 2009.

Düvel, K.; Yecies, J. L.; Menon, S.; Raman, P.; Lipovsky, A. I.; Souza, A. L.; Triantafellow, E.; Ma, Q.; Gorski, R.; Cleaver, S.; Vander Heiden, M. G.; MacKeigan, J. P.; Finan, P. M.; Clish, C. B.; Murphy, L. O. \& Manning, B. D. Activation of a metabolic gene regulatory network downstream of mTOR complex 1. Mol. Cell, 39(2):171-83, 2010.

Fávaro, W. J. \& Cagnon, V. H. A. Morphometric and morphological features of the ventral prostate in rats submitted to chronic nicotine and alcohol treatment. Tissue Cell, 38(5):311-23, 2006.

Gallagher, P. M.; Carrithers, J. A.; Godard, M. P.; Schulze, K. E. \& Trappe, S.
W. Beta-hydroxy-beta-methylbutyrate ingestion, Part I: effects on strength and fat free mass. Med. Sci. Sports Exerc., 32(12):2109-15, 2000.

Gerlinger Romero, F.; Guimarães-Ferreira, L.; Giannocco, G. \& Nunes, M.T. Chronic supplementation of beta-hydroxy-beta methylbutyrate (HMB) increases the activity of the GH/IGF-I axis and induces hyperinsulinemia in rats. Growth Horm. IGF Res., 21(2):57-62, 2011.

Helgerud, J.; Rodas, G.; Kemi, O. J. \& Hoff, J. Strength and endurance in elite football players. Int. J. Sports Med., 32(9):677-82, 2011.

Karrasch, T.; Spaeth, T.; Allard, B. \& Jobin, C. PI3K-dependent GSK3B(Ser9)phosphorylation is implicated in the intestinal epithelial cell wound-healing response. PLoS One, 6(10):e26340, 2011.

Kraemer, W. J.; Hatfield, D. L.; Volek, J. S.; Fragala, M. S.; Vingren, J. L.; Anderson, J. M.; Spiering, B. A.; Thomas, G. A.; Ho, J. Y.; Quann, E. E.; Izquierdo, M.; Häkkinen, K. \& Maresh, C. M. Effects of amino acids supplement on physiological adaptations to resistance training. Med. Sci. Sports Exerc., 41(5):1111-21, 2009.

Manning, B. D. \& Cantley, L. C. AKT/PKB signaling: navigating downstream. Cell, 129(7):1261-74, 2007.

Melnik, B. C.; John, S. M.; Carrera-Bastos, P. \& Cordain, L. The impact of cow's milk-mediated mTORC1-signaling in the initiation and progression of prostate cancer. Nutr. Metab. (Lond.), 9(1):74, 2012

Misra, U. K. \& Pizzo, S. V. Evidence for a pro-proliferative feedback loop in prostate cancer: the role of Epac1 and COX-2-dependent pathways. PLoS One, 8(4):e63150, 2013

Pimentel, G. D.; Rosa, J. C.; Lira, F. S.; Zanchi, N. E.; Ropelle, E. R.; Oyama, L. M.; Oller do Nascimento, C. M.; de Mello, M. T.; Tufik, S. \& Santos, R. V. b-Hydroxy-b-methylbutyrate (HMb) supplementation stimulates skeletal muscle hypertrophy in rats via the mTOR pathway. Nutr. Metab. (Lond.), $8(1): 11,2011$.

Powers, G. L. \& Marker, P. C. Recent advances in prostate development and links to prostatic diseases. Wiley Interdiscip. Rev. Syst. Biol. Med., 5(2):243$56,2013$.

Teixeira, G. R.; Fávaro, W. J.; Pinheiro, P. F.; Chuffa, L. G.; Amorim, J. P. Mendes, L. O.; Fioruci, B. A.; Oba, E.; Martins, O. A.; Martinez, M. \& Martinez, F. E. Physical exercise on the rat ventral prostate: steroid hormone receptors, apoptosis and cell proliferation. Scand. J. Med. Sci. Sports, 22(5):e86-92, 2012.

Teixeira, G. R.; Gobbo, L. A.; dos Santos, N. J.; de Araújo, R. G.; dos Santos, C. C.; de Mello Malheiro, O. C.; Castoldi, R. C.; Camargo-Filho, J. C. S. \& Papoti, M. The effect of b-hydroxy-b-methylbutyrate (HMB) on the morphology of skeletal muscle after concurrent training. Motriz, Rev. Educ. Fis., 22(3):190-7, 2016.

Voltarelli, F. A.; Gobatto, C. A. \& de Mello, M. A. Determination of anaerobic threshold in rats using the lactate minimum test. Braz. J. Med. Biol. Res. 35(11):1389-94, 2002

Weibel, E. R.; Kistler, G. S. \& Scherle, W. F. Practical stereological methods for morphometric cytology. J. Cell Biol., 30(1):23-38, 1996.

Wu, Y.; Chhipa, R. R.; Cheng, J.; Zhang, H.; Mohler, J. L. \& Ip, C. Androgen receptor-mTOR crosstalk is regulated by testosterone availability: implication for prostate cancer cell survival. Anticancer Res., 30(10):3895$901,2010$.

Corresponding author:

Giovana Rampazzo Teixeira

Department of Physical Education

State University (Unesp)

School of Technology and Sciences

19060-900, Presidente Prudente SP

BRAZIL

E-mail: giovana@fct.unesp.br

Received:30-08-2017

Accepted:20-10-2017 